\title{
UNDERSTANDING OF TAX RULES, TAX TARIFFS AND TAX-RIGHTS CONSCIOUSNESS ON E-COMMERCE USERS TAX COMPLIANCE
}

\author{
Rendy, Wiwit Irawati \\ Universitas Pamulang \\ dosen00869@unpam.ac.id
}

\begin{abstract}
The purpose of this study was to determine the effect of Understanding Tax Regulations, Tax Rates and Taxpayer Awareness on Taxpayer Compliance with e-Commerce users. The research method used is quantitative research using a questionnaire, this research is distributed to 100 Online Shopping Taxpayers in Depok City. The sample collection technique is Convenience Sampling, data analysis in this study was conducted using data quality test, classic assumption test, multiple regression analysis, $t$ test, $F$ test and test coefficient of determination. The results showed that partially understanding of tax regulations does not affect the compliance of e-Commerce taxpayers, tax rates do not affect the compliance of e-Commerce taxpayers, taxpayer awareness affects e-Commerce users' taxpayer compliance. While simultaneously Understanding Tax Regulations, Tax Rates and Taxpayer Awareness influences the Taxpayer Compliance with e-Commerce users.
\end{abstract}

Keywords: Understanding of Tax Regulations, Tax Rates, Taxpayer Awareness, Compliance of Taxpayers of e-Commerce users

\section{INTRODUCTION}

E-Commerce Transactions are business transactions carried out electronically so that transactions between buyers and traders can make any sale and purchase transactions, anytime, anywhere. This flexibility makes e-Commerce trading favored by the modern society of internet users. The development of information and communication technology has led to the transformation of business models and strategies that need to be emphasized in terms of taxation.

Internet technology has a very large influence on the world economy, the more economic activities carried out using internet media one of which is in the field of trade or can be called
Electronic Commerce (electronic commerce). As part of Electronic

Business (business carried out using electronic transmission) can be defined generally as all forms of trade transactions or trade in goods or services (trade of goods and services) using electronic media.

The imposition of income tax on online businesses is that the taxes charged to online shop owners have not been effective as a whole, even online shop owners do not pay their taxes, one logical answer to the problem is that many people in this country have not known taxation, not even a few who knew nothing or were blind about the science of taxation. Indonesia Country Head of ShopBack Indra Yonathan sees the e-commerce industry in Indonesia in 
2019 will be more directed and growing. This year, e-commerce players are predicted to be more aggressive in bringing innovations to attract new consumers and retain old consumers. Discounted promo and other promos will continue to color e-commerce 2019.

Meanwhile, as an e-commerce aggregator platform, ShopBack also sees trends in digital trading in Indonesia in 2019. Transactions through mobile devices are believed to continue to increase. Connected, access the internet through a smartphone device. The average community spends 4 hours accessing the internet through mobile devices. Even $68 \%$ of connected communities are online shopper, who use mobile / smartphine devices to find the desired product.

Another trend, sales from social media will tend to decline, slowly MSMEs who sell on social media platforms are beginning to penetrate and enter into e-commerce platforms. The selling value of local products is quite high in Harbolnas last year, making MSMEs optimistic that they can expand their business if they join an ecommerce platform. In addition, the ease of data collection on customers and the indirect marketing budget is provided by the e-commerce platform. This is the reason MSMEs started trying to join the e-commerce platform.

Considering the number of internet users that have an impact on the increase in turnover of electronic commerce in fact raises several problems in the financial sector, one of which is the internet sales tax. Electronic commerce that knows no geographical boundaries raises questions about how tax regulations are in anticipation of income from e-commerce transactions, because without proper tax regulations on ecommerce transactions, the potential for tax revenue from e-commerce transactions can be lost.
Tax withdrawal of e-commerce transactions aims to implement justice for all taxpayers, both conventional and e-commerce. As reported by the official website http://www.pajak.go.id/, basically the e-commerce and conventional taxpayer obligations are no different. The Directorate General of Tax of the Ministry of Finance (DGT of the Ministry of Finance) revealed that it has included the potential for tax revenues from e-commerce companies to the 2017 State Revenue and Expenditure Budget (https://www.cnnindonesia.com/).

Rifa Arbangatin Hasanah 2016) states that e-commerce is a dynamic technology, application, and business process that connects companies, consumers, and certain communities through electronic transactions and trade in goods, services, and information carried out electronically. e-commerce refers to all forms of commercial transactions involving organizations and individuals that are based on the process and transmission of data digitalized, including text, sound and images.

In contrast to ordinary trade transactions in general, e-commerce transactions have some very special characteristics that result in tax implications that are complicated by these activities. This happens because electronic transactions between emerchants, (parties who buy goods or services through the internet) that occur in cyberspace or on the internet generally take place in a paperless transction, while the documents used in these transactions are not paper documents, but electronic documents (digital document).

Previous research conducted by (Nadia Mulijadi: 2017) entitled "The Effect of e-Commerce Owner's Knowledge Level on the level of Compliance with Tax Payments for eCommerce Transactions". The results showed that e-commerce owners in the 
city of Bandung knew enough about the tax regulations on e-commerce transactions, although there were still many who did not know how to pay taxes or e-commerce transactions. While the level of compliance also obtained results that e-commerce owners are quite obedient. This means that there are still many e-commerce owners who do not pay taxes on e-commerce transactions.

\section{LITERATURE REVIEW}

e-Commerce is where on a website provides or can make transactions online or also can be a way of shopping or trading online or direct selling that utilizes internet facilities where there are websites that can provide "get and deliver" services. e-Commerce will change all marketing activities and also at the same time reduce operational costs for trading (trading) activities. The benefits obtained by using transactions through e-commerce for a company are as follows:

1. Increase revenue by using online channels that are cheaper.

2. Reducing the costs associated with paper, such as baiaya postal mail, printing, reports, and so on.

3. Reducing delays by using electronic transfers or payments that are on time and can be immediately checked.

4. Speed up customer service, and service is more responsive.

According to Gunadi (2013: 94) the notion of taxpayer compliance is: "In this case it means that taxpayers have a willingness to fulfill their tax obligations in accordance with applicable rules without the need for checks, careful investigations, warnings or threats and the application of legal and administrative sanctions

Taxpayer compliance is the fulfillment of tax obligations carried out by taxpayers in order to contribute to development. Nowadays what is expected in the fulfillment is given voluntarily. Compliance with taxpayers is an important aspect considering that the Indonesian taxation system adheres to a system of assessments in which the process absolutely gives confidence to taxpayers to calculate, pay, and report their obligations.

Knowledge and understanding of tax regulations is the process by which taxpayers know about taxation and apply that knowledge to pay taxes. Rifa Abangatin Hasanah (2016) found that the low level of taxpayer compliance was due to the knowledge of taxpayers as well as perceptions of taxes and tax officers who were still low. Some taxpayers obtain tax information from tax officers, besides that there are those who obtain tax information from information media, tax consultants, seminars and tax training. Understanding of tax regulations is a process whereby taxpayers understand and know about rules and regulations as well as taxation procedures and apply them to carry out tax activities such as paying taxes, reporting tax returns, and so on. If someone has understood and understood taxation, there will be an increase in tax compliance. Tax payer knowledge of tax regulations is certainly related to the understanding of a taxpayer about tax regulations.

To calculate the amount of tax payable, two elements are required, namely the tax rate and tax base. Tax rates can be a number or a certain percentage. The types of tax rates are divided into fixed tariffs, proportional rates (comparable), progressive tariffs (increases), and degenerative tariffs (decreasing).

Consciousness is an element in humans to understand reality and how they act or act in reality. Some forms of awareness pay taxes that encourage taxpayers to pay taxes. First, awareness 
that taxes are a form of participation in supporting the country's development. In realizing this, taxpayers are willing to pay taxes because they feel they have not been harmed by the tax collection. Second, awareness that delaying tax payments and reducing tax burden is very detrimental to the state.

Taxpayers are willing to pay taxes because they understand that delaying tax payments and reducing tax burdens have an impact on the lack of financial resources that can result in impeded state development.

\section{RESEARCH METHOD}

This study uses a quantitative approach with a survey method. Through this method, data sampling is carried out using a questionnaire distributed randomly to respondents as a data collection tool.

The population in this study were all individual taxpayers totaling 310,230 taxpayers in the city of Depok. The research uses the Slovin formula, so that the samples taken in this study were 100 taxpayers of e-commerce users in online shopping entrepreneurs in Depok City. This sampling is done by convenience sampling method, which is a method of sampling freely and conditionally without determining the status, or condition of the respondent, so as to make the researcher comfortable and easy in taking samples.

The type of data used in this study, namely primary data. The mathematical formula of multiple regression used in this study is:

$$
\begin{array}{ll}
\mathrm{Y} & =\mathrm{a}+\mathrm{b} 1 \mathrm{X} 1+\mathrm{b} 2 \mathrm{X} 2+\mathrm{b} 3 \mathrm{X} 3+\mathrm{e} \\
& \text { Description: } \\
\mathrm{Y} & =\text { Compliance with e-taxpayer } \\
& \text { Commerce } \\
\mathrm{a} & =\text { constanta } \\
\mathrm{b} 1 & =\text { Regression coefficient between } \\
& \text { understandings tax regulations }
\end{array}
$$

with taxpayer compliance with e-commerce users

b2 = Regression coefficient between tax rates with taxpayer compliance with e-commerce users

b3 = Regression coefficient between consciousness taxpayer with taxpayer compliance with ecommerce users

$\mathrm{X} 1=$ Variation of Tax Regulation Termination

$\mathrm{X} 2=$ Variable Tax Rates

X3 = Taxpayer Awareness Variable

$\mathrm{e} \quad=$ error disturbances

In proving the correctness of the hypothesis test proposed, a statistical

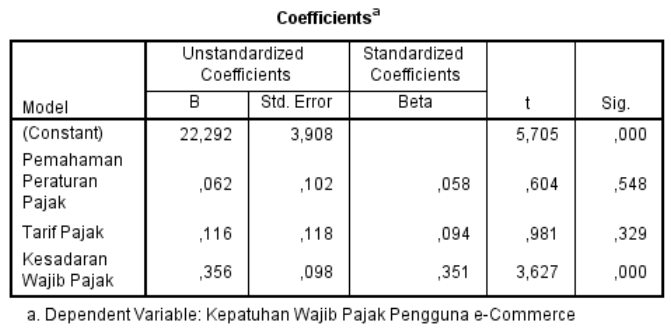

test of the output produced from the regression equation is used.

\section{RESULTS AND DISCUSSION}

Results

Hypothesis testing is done by using the Multiple Linear Regression method which aims to examine the effect of the relationship between one variable to another variable. Data analysis used multiple regression statistical techniques to test the effect of independent variables on the dependent variable, namely to find out whether there was an influence between understanding tax regulations, tax rates and taxpayer awareness of taxpayer compliance with e-commerce users. Multiple linear regression analysis is used in this study with the aim to determine whether there is an influence of independent variables on the dependent variable. The statistical 
calculation in multiple linear regression analysis used in this study is to use the help of a computer program SPSS for Windows version 22 summary of the results of data processing using the SPSS program are as follows:

From the results of the multiple regression analysis above, multiple regression equations are obtained as follows:

$\mathrm{Y}=\mathrm{a}+\beta 1 \mathrm{X} 1+\beta 2 \mathrm{X} 2+\beta 3 \mathrm{X} 3+\mathrm{e}$

$\mathrm{Y}=22,292+0,062 \mathrm{PPP}+0,116 \mathrm{TP}+$ $0,356 \mathrm{KWP}+\mathrm{e}$

The regression equation can be explained as follows:

1. Regression coefficient of Understanding the Tax Regulation (X1) is positive, which is 0.062 . This means that there is an influence of Understanding Tax Regulations (X1) on Taxpayer Compliance with e-Commerce users. In other words, if the understanding of tax regulations is increased, Tax Compliance with Tax E-Commerce users will also increase with an increase in value of 0.062 .

2. Regression coefficient of Tax Rate variable (X2) is positive, which is 0.116 . This means that there is an influence of Tax Rates (X2) on Taxpayer Compliance with eCommerce users. In other words, if the Tax Rate is increased then the Compliance of Tax Magic of eCommerce users will also increase with an increase in value of 0.116 .

3. Regression coefficient of Taxpayer Awareness variable (X3) is positive, which is 0.356 . This means that there is an influence of Tax Payer Awareness (X3) on Taxpayer Compliance with eCommerce users. In other words, if the Taxpayer's Awareness is increased, the Tax Magic Compliance of e-Commerce users will also increase with an increase in value of 0.356 .
Standard error (e) is a random variable and has a probability distribution. Standard error (e) represents all factors that have an influence on $\mathrm{Y}$ but are not included in the equation

\section{Discussion}

The discussion of the results of the following research is adjusted through the formulation of the problems contained in this study.

\section{Effect of Understanding Tax Regulations on Compliance with e- Commerce User Taxpayers \\ Based on partial hypothesis} testing ( $\mathrm{T}$ test) shows that the Understanding of Tax Regulations (X1) has $\mathrm{T}$ count $<\mathrm{T}$ table which is 0.604 $<1.985$ or sig value $0.548>\alpha 0.05$ means $\mathrm{H} 1$ is rejected. This shows that the Understanding of Tax Regulations (X1) does not partially affect the compliance of e-Commerce taxpayers (Y). This shows that the higher or lower understanding of taxpayers regarding tax regulations, will not affect e-Commerce users' taxpayer compliance itself. This is because taxpayers can use tax consultants in calculating their taxes, besides that many taxpayers do not understand in detail related to all existing tax regulations, starting from the functions and benefits of taxes, how to fill in the tax return, to how to calculate the amount of tax borne.

The results of this study are consistent with the research conducted by Nelsi Arisandy (2017) which shows the results that the understanding of taxpayers regarding tax regulations does not significantly influence individual taxpayer compliance with online business activities in Pekanbaru. But it is inversely proportional to the research conducted by Rifa Abangatin Hasanah (2016) who suggests that understanding tax rules significantly influences eCommerce users' taxpayer compliance. 


\section{Effect of Tax Rates on Compliance with e-Commerce Users Taxpayers \\ Based on partial hypothesis} testing ( $\mathrm{T}$ test) shows that the Tax Rate variable $(\mathrm{X} 2)$ has $\mathrm{T}$ count $<\mathrm{T}$ table that is $0.981<1.985$ or sig value $0.329>\alpha$ 0.05 means $\mathrm{H} 1$ is rejected. This shows that the Tax Rate (X2) does not partially affect the compliance of e-Commerce taxpayers $(\mathrm{Y})$. In this study, the tariff in question is $0.5 \%$ of business turnover for one year. The data above illustrates that the latest regulation PP No. 23 of 2018 which sets a tax levy rate of $0.5 \%$ for taxpayers who have an income of no more than 4.8 billion in one year, does not affect taxpayer compliance. This is because no matter how much the tax rate is charged to taxpayers, taxpayers are supposed to pay at this rate, because the tariff has already been determined by tax laws in Indonesia. In addition, the tax rate set by the government at $0.5 \%$ is considered still burdensome to online shooping businesses, because their average turnover in one month is still below 300 million.

In this study, it is in line with the research conducted by Rifa Abangatin Hasanah (2016) which shows the results that tax rates do not positively affect taxpayer compliance because the income of most of the respondents is still below $<300$ million. Based on respondents' answers, the tariff is still not fair, especially for taxpayers who have small turnover.

Effect of Taxpayer Awareness on Compliance with e-Commerce User Taxpayers

Based on partial hypothesis testing ( $\mathrm{T}$ test) shows that the Taxpayer Awareness variable (X3) has a T count> $\mathrm{T}$ table that is $3.627>1,985$ or sig value $0,000<\alpha 0.05$ means H1 is accepted. This shows that Taxpayer Awareness (X3) has a partial effect on e-Commerce users' Tax Compliance (Y). Taxpayers are aware of paying taxes voluntarily and consciously as an actualization of the spirit of mutual cooperation or national solidarity to build the national economy. If the taxpayer is aware of his obligation to pay taxes, then the taxpayer will comply.

The results of this study are consistent with the research conducted by Nelsi Arisandy (2017) and also Novita Eka Sari (2016) which shows the results that taxpayer awareness has a significant effect on taxpayer compliance with e-commerce users. From these results it can be concluded that the obligation to pay taxes is the mandate of your country for the people of that country to run. A good mandate if it has been given will produce something good too. Therefore, the awareness of each taxpayer to fulfill his tax obligations should be raised and raised.

\section{Simultaneous Influence of Understanding Tax Regulations, Tax Rates and Taxpayer Awareness on Compliance with e-Commerce Users Taxpayers}

The results of the analysis show that simultaneously there is an influence between Understanding of Tax Regulations (X1), Tax Rates (X2) and Taxpayer Awareness (X3) on eCommerce users Taxpayer Compliance (Y). Based on the results of simultaneous hypothesis testing (Test F) conducted, it was obtained that the results of $F$ count $>F$ table, 5.924> 2.46 Which can be interpreted that simultaneously the independent variable Understanding Tax Regulations, Tax Rates, and Awareness of Taxpayers influential together- same for eCommerce users Taxpayer Compliance. These results reinforce previous research conducted by Rifa Abangatin Hasanah (2016), namely the Effect of Understanding Tax Regulations, Tax Rates, and Taxpayer Awareness on 
Taxpayer Compliance with e-Commerce users.

This shows that e-commerce business users namely online shopping have understood the existing tax regulations. This is also influenced by the awareness of each individual. Significant influence can also illustrate that with the understanding of regulations regarding taxes, the public, especially online shopping entrepreneurs, are more obedient to the obligations they must perform.

\section{CONCLUSION}

\section{Conclusion}

The purpose of this study is to know the effect of understanding tax regulations, tax rates and taxpayer awareness of taxpayer compliance with e-commerce users. Respondents in this study amounted to 100 respondents.

From the results of testing the hypothesis by using multiple regression tests, partially, the variable understanding of taxpayers does not significantly influence the compliance of individual taxpayers who carry out online business activities in Pekanbaru. This shows that the higher or lower understanding of taxpayers, will not affect the level of taxpayer compliance itself.

Likewise also with the Tax Rate partially does not affect the Taxpayer Compliance of e-Commerce users. This is because no matter how much the tax

\section{REFERENCES}

, Peraturan Pemeritah No. 23 Tahun 2018 Tentang PPh Atas Penghasilan Yang Diterima Atau Diperoleh Wajib Pajak Yang Memimiliki Peredaan Bruto Tertentu rate is charged to taxpayers, taxpayers are supposed to pay at this rate, because the tariff has already been determined by tax laws in Indonesia.

\section{Suggestion}

1. For the Directorate General of Taxes

The need to improve socialization carried out by the government, especially the Directorate General of Taxes, either through mass media or socialization directly in the field.

2. For Online Shopping Entrepreneurs For taxpayers (Online Shopping Entrepreneur), awareness needs to be improved in order to understand the existing tax regulations, register as a taxpayer, and fulfill their obligations. Because online shopping entrepreneurs are the same as ordinary entrepreneurs, both earning income. And should have paid the tax due.

3. For the community

There needs to be a good understanding especially regarding the implementation of tax collection from e-commerce actors, so that people who have businesses in online shopping businesses can be aware and obey the obligation to pay taxes. 
Devano, Sony dan Siti Kurnia Rahayu, (2006). Perpajakan: Konsep, Teori, dan Isu. Kencana, Jakarta.

Dwi, Priyatno. (2009). 5 Jam Belajar Olah Data dengan SPSS. Yogyakarta: Andi

Gunadi. (2013). Panduan Komprehensif Pajak Penghasilan. Jakarta: Bee Media Indonesia

Halim, Abdul dan Teguh, (2006), eCommerce. Yogyakarta: Pustaka Pelajar.

Hidayat, A., \& Yuliah, N. (2018). The Effect of Good Corporate Governance and Tax planning on Company Value. EAJ (Economics and Accounting Journal), 1(3), 234-241

Nurmantu, Safri. (2009). Pengantar Perpajakan. Jakarta : Granit.

Iskandar. (2008). Metodologi Penelitian Pendidikan dan Sosial (Kuantitatif dan Kualitatif). Jakarta: GP Press.

Rahayu, Siti Kurnia. (2013). Perpajakan Indonesia Konsep dan Aspek Formal. Yogyakarta: Graha Ilmu
R. Santoso Brotodihardjo. (2003). Pengantar Ilmu Hukum Pajak. Refika Aditama. Bandung.

Resmi, Siti. (2014). Perpajakan Teroi dan Kasus, Buku 1 edisi 8. Salemba Empat. Jakarta

Singarimbun, Masri dan Sofian Efendi. (1995). Metode Penelitian Survey. PT. Pustaka LPES. Jakarta

Siregar, Syofian. (2013). Statistik Parametrik Untuk Penelitian Kuantitatif. Jakarta: Rineka Cipta.

Sugiyono. (2012). Metode Penelitian Kuantitatif Kualitatif Dan $R \& D$. Bandung: Alfabeta.

Suwardi, (2011). Menuju Kepuasan Pelanggan Melalui Penciptaan Kualitas Pelayanan. Politeknik Negeri Semarang. Semarang.

Http://ekbis.sindonews.com/read/137359 8/34/industri-e-commerce-diyakinimasih-menjanjikan-di-20191548420369

http://junaidichaniago.wordpress.com http://www.pajak.go.id 